\title{
Women Writers in India: Tracing Feminism
}

\author{
Ms. Bharti, Dr. Shriya Goyal \\ Uttaranchal University, Dehradun
}

\begin{abstract}
From pre-Independence period to the contemporary times, women's voice is gradually being heard and gaining momentum. It is hoped as well as expected that women would soon become a prominent voice making a mark in the society. Their point of view along with their decision making authority will have a definite and constructive impact on the society. This can be inferred from the literature by various Indian women writers such as Pandita Ramabai, Ismat Chughtai, Kamala Das and Shashi Deshpande. As we move from one decade to another entering the $21^{\text {st }}$ century, we observe how women have been able to break the cocoon of domesticity, marking their presence in various socio-political spheres which have been usually dominated by men. Women have sought their space for expression and voicing opinion through literature. Depicting the oppression and discrimination faced in the patriarchal setup of Indian society, the women writers have pointed at the need for equality in practice as well as representation. The article will provide a discussion regarding Feminism in India, analysing each period or phase along with a women writer.
\end{abstract}

Article Received: 18 October 2020, Revised: 3 November 2020, Accepted: 24 December 2020

Considering the fact that India is a large diverse country, one can observe that the surge of feminism or feminist voices was different or rather uneven. One also needs to understand that several socio- cultural aspects such as class, caste, religion and region have certain implications when it comes to addressing the women's issues. The emergence of women's movement in India can be marked by some relevant shifts as given by Maitrayee Chaudhari:

1. $19^{\text {th }}$ century Social Reform Movements, which further nurtured the growth of women's writing in India.

2. Political participation by women and formation of several women's groups around early $20^{\text {th }}$ century.

3. Feminism during the post Independence period.

4. New perspectives and changes in feminism in late $20^{\text {th }}$ century.

\section{Social Reform Movements}

Social Reform Movements were a part of the late $17^{\text {th }}$ to early $20^{\text {th }}$ centuries in India. During this period India possessed a still traditional society in the throes as well as the creative excitement of modernity and that of emerging as a new nation. The $19^{\text {th }}$ century initiated this process of transformation in the religious, social, economic, political and cultural spheres. The impact of the
British Empire influenced administration, legislation, trade, network of communications, industrialisation and urbanisation in India, affecting not only the society as a whole but also the traditional patterns of life. British scholars, educators and missionaries also left a major impact in the traditional field. The reformers consciously reacted to the new situation and advocated deliberate changes in social and religious attitudes and customs of the Indian population.

The reform movements were directed against several evil customs and practices which were a part of the Hindu social systems such as sati, child marriage, female infanticide and belief in superstitions. These discriminatory customs were fought with determination by reformers like Raja Ram Mohan Roy, Ram Krishna Paramhans, Swami Dayanand, Ishwar Chandra Vidyasagar, Sir Sayed Ahmed Khanand others. As a result of these movements significant advances were made for emancipation of women.

\subsection{Pandita Ramabai}

Pandita Ramabai (1858-1922) was awarded the title "Pandita" in recognition of her great learning. Ramabai's first teacher was her mother. Anant Padmanabha Dongre, Ramabai's father, was a great Vedic scholar who decided to educate his 
wife over the objections of the community. Ramabai's education began at eight and continued until she was fourteen. She memorised the Bhagavata Purana and the Bhagavata Gita; then studied Sanskrit grammar and vocabulary.

Pandita Ramabai was truly remarkable as a pioneer in women's education and women's rights. At the age of sixteen her parents died, at this time she was unmarried and able to read Sanskrit. She and her brother travelled throughout India lecturing on female education and social reform. Ramabai's brother died in Calcutta and she married his close friend Bipen Behari Das. The next year, at age twenty-three, Ramabai gave birth to a daughter. Unfortunately her husband died the following year. She began to work with reformers to educate women through the Arya Mahila Samaj in Poona. In order to learn English and study medicine, Ramabai sought help from members of the Anglo-catholic community. They were able to provide her some assistance while the balance of her expenses were met through the sale of her book Stri Dharma Neeti (Morals for Women), which urged women to take charge of their own lives. In 1883, she left for England with her daughter, where she decided to accept baptism. She continued her studies until 1886 when she decided to sail for America to attend the graduation ceremony of her cousin.

Ramabai wrote The High Caste Hindu Woman to finance her trip and popularise her cause. Ten thousand copies of this book were sold before Ramabai had left America. In 1887, a Ramabai Association was set up by the Boston admirers to support her work in India. She travelled throughout the United States and Canada studying educational, philanthropic and charitable institutions and lecturing to various groups.

In India Padita Ramabai established Sharda Sadan (Home of Wisdom), a school for widows in Bombay. This was to be a non sectarian school where all the caste rules of Brahmins were scrupulously observed and it attracted some high caste widows.
By 1900 the Sharda Sadan has trained eighty women who were able to earn their own living through teaching or nursing. Ramabai's second school, Mukti, was established thirty miles outside of Poona at Kedgoan following the famine that began in 1879. It soon grew into a major institution by 1900 , housing 2,000 women and children attending school and involved in industrial training and production.

\section{Early $20^{\text {th }}$ century}

The period after Social Reform Movements, during the Nationalist Movement, reflects an era of localised women's associations emerging. The All India Women's Conference (AIWC), a national level women's association was closely affiliated to the Indian National Congress. Under the leadership of Mahatma Gandhi it worked within the nationalist and anti- colonialist freedom movements. Apart from AICW, there were other organisations such as the All India Muslim Ladies' Conference (1914), the Women's India Association (WIA 1917), and the National Council of Women in India (NCWI 1925). An important idea was the thought process that a society advances when the women progress alongside men.

\subsection{Ismat Chughtai}

Ismat Chughtai (21 August 1915 - 24 October 1991) has written extensively on themes such as female sexuality and femininity, and class conflict. Her works reflect literary realism, and she has successfully carved a niche for herself in the Urdu literature of the twentieth century. She was awarded the Padma Shri by the Government of India in 1976.Though there was a strong resistance from her mother regarding her wish to pursue education, she completed her Bachelor of Education degree from the Aligarh Muslim University and it was during this period that she became a part of the Progressive Writers' Association.

A prolific Urdu writer, who has written about marginalized people, such as women of minority 
communities, widows, prostitutes, beggars, and all those women who have been oppressed by the Indian patriarchal society, Ismat Chughtai has depicted through her literature the lives of middle class women belonging to Muslim as well as Hindu communities. Ismat Chughtai is known for her bold and controversial style of writing, a way to comment upon the double standards that dominated women in society. Chughtai also led her female contemporaries on a remarkable journey of self-awareness and undoubted creative expression.

Chughtai's first novella Ziddi (1941), narrates the love affair between a female domestic help in a rich household and her employer's son. Chughtai caught reader's attention for her short-story "Lihaaf" (The Quilt, 1942), which was written based on the rumoured affair of a begum and her masseuse. This story explores the sexual awakening of Begum Jan and gives an insight into her unhappy marriage with a nawab. Upon its release, the story attracted criticism as it suggested female homosexuality.

Tedhi Lakeer (The Crooked Line), Chughtai's semi-autobiographical novel was released in 1943 while she was pregnant with her daughter. The book gives an insight into the Muslim community, and specifically the condition of women. Chughtai's exploration of the inner quarters of women's household was well received by the critics. She has often recalled in her interviews that she found inspiration from the small incidents that she observed around her including the personal conversations of the women in her family.

True to her style, Ismat's autobiography Life in Words: A Memoir is honest, ironical, expressive, and highly spirited. The opening chapter is about becoming a writer and her first realisation regarding the world in which she lives. She has also bluntly discussed the court case of obscenity in the story "Lihaaf" Themes such as homosexuality and female sexuality brought her story fame but also dragged her to the court. She highlighted certain intricate aspects of female sexuality and other sexual experiences, making it an essential part of her art. Chughtai breaks away from the silence of oppression by writing and creating a platform for expression of female aesthetics. She has proven via her literature how femininity is socially and culturally constructed rather than being an essential trait.

\section{Independence and post Independence}

Along with getting Independence in 1947, India was also partitioned into two- India and Pakistan. This led to an upsurge of violence amongst people who have lived together for generations. It seemed as if the women's issues were forgotten in the public eye. Many feminist scholars have also written about the tragic narratives of women during the partition violence, but certainly somewhere the women's issues were brushed aside. But soon this silence was overcome with another wave of women's movement in the 1960s -1970 s.

\subsection{Kamala Das}

Kamala Surayya (31 March 1934 - 31 May 2009), also known by her pen name Madhavikutty and later Kamala Das, was a prolific Indian English poet and an author from Kerala. She is noted for her poems and expressive autobiography. She has written extensively on diverse topics such as women's issues, child care, and socio- political situations. Her honest opinion and free expression of female sexuality, reflects a sense of power and freedom, as an inspiration for her readers. She wrote both in Malayalam and English, eventually recognised by the PEN Asian Poetry Prize in 1963.

Kamala Das' bold expression is a prominent feature of her works including poetry, which is often written in confessional mode. Her poetry is a reflection of herself. As a poet, her work is filled with the theme of love, relationships, sex and their complexities. She makes sure that such taboo topics are openly discussed, topics towards which 
the Indian society usually turns a blind eye. Her famous stories are "Chandana Marangal", "Neypayasam", "Thanuppu”, and "Pakshiyude Manam". Her novel Neermathalam Pootha Kalam stands out as one of her best work. Her other published works are Summer in Calcutta (1965), The Descendants (1967), The Old Play House and Other Poems (1973), Tonight, this Savage Rite: The Love Poems of Kamala Das and Pritish Nandy (1979), The Annamalai Poems (1985), Only the Soul Knows How to Sing (1996) and Ya Allah (2001).

My Story is her autobiographical book originally published in Malayalam, titled Ente Katha. The book evoked different reactions of both admiration and criticism and is still known to be a best-selling woman's autobiography in India. The text is realist, written in a linear narrative, where the author has penned down the painful trials of her marriage and her self-awakening as a woman and a writer. The autobiography is indeed outspoken, creating controversial stirs but honest at the same time. The major themes highlighted are marriage, love, desire and fulfillment, trust and betrayal. There is a description of an incomplete, unfulfilled journey of a woman searching for true love. It is a piece of art created by an Indian woman surrounded by the patriarchal society which expects her to remain confined in the domestic sphere. The book makes an attempt to highlight the individualistic and feministic approaches.

\section{Late $20^{\text {th }}$ century}

The women's movement in the 1980s emerged parallel to the second wave of feminism in the West. Many issues raised and challenged during this period included divorce laws, custody, guardianship, sexual harassment, dowry, rape and political representation. This period saw the women's question being discussed publicly and also gained a lot of media attention. Some of the biggest achievements during these years were the legal reforms. Not only had the Indian women's movement gained momentum in the global front but the Indian feminist writings were also recognised worldwide. The issues concerning the peasant women and rural society were highlighted, making it a movement encompassing various sections of the society.

\subsection{Shashi Deshpande}

Shashi Deshpande is a famous name in Indian literature. She has received degrees in Economics, Law and Journalism and began her career as a journalist in the magazine Onlooker. The initial phase of her career was when her short stories were published in popular magazines like Femina and Eve's Weekly in Mumbai while she was raising her two sons. The collection of short stories was published as "Legacy" in 1978 and first novel, The Dark Holds No Terrors in 1980. Her novel titled That Long Silence brought her fame and appreciation and she even received the Sahitaya Akademi Award and Nanjangud Thirumalamba award.

Listen To Me, a title given appropriately to her autobiography is a retelling of the author's life. The book is written in a very delightful manner holding layers of back story. It showcases her journey as a writer which she began after the realisation that being circumscribed in the domestic life was not enough. The book also showcases some insightful incidents about the life of women writers and the discrimination they come across at several levels. Deshpande's memoir is able to highlight the male dominance in the world of literature which leads to gendered notions further strengthening patriarchy.

Shashi Deshpande's work portrays women's journey of struggle and survival in India. Her literature highlights the sufferings of women, their everyday reality. The novels showcase women characters' quest for self, an insight into the female psychology and an awareness of the predicaments of life in which these women are situated. In 1978 her first collection of short stories was published, titled The Legacy and other 
Stories. Her other published work includes: It was Dark, The Miracle, It was the Nightmare and The Intrusion and other stories. The Dark Holds No Terrors (1980), If I Die Today (1982), Come Up and be Dead (1983), Roots and Shadows (1983), That Long Silence (1988), The Binding Vine (1992), A Matter of Time (1996) and Small Remedies (2000) are considered to be relevant contributions to Indian writing. An analysis of Shashi Deshpande's texts brings out her representation of women characters and their troubles. She provides an insight into a woman's mind highlighting the secondary treatment meted out to women in Indian patriarchal society.

\section{Conclusion}

Though all advancements have been made politically and constitutionally, one still needs to consider the deeply rooted subconscious patriarchal notions of the society and develop a more holistic approach in this direction. Most prominent women writers who have given voice to the unheard women of the society in India are Pandita Ramabai, Ismat Chughtai, Kamala Das and Shashi Deshpande. The four writers span over various phases of Indian Feminism. Their works have left an indelible mark in the history of Indian literature and also played an important role in presenting the gender issues prevailing in the society.

\section{Bibliography}

[1] Aleeba, Fatima. Feminist perspectives in the Select works of Virginia Woolf and Ismat Chughtai a Comparative Study. 2018. Retrieved from http://hdl.handle.net/10603/291152

[2] Anjum, Tasneem. Kamala Das a Feminist Writer. 2000. Retrieved from http://hdl.handle.net/10603/217784

[3] Chaudhuri, M. (2012). FEMINISM IN INDIA: THE TALE AND ITS TELLING. Revue Tiers Monde, (209), 19-36. Retrieved from www.jstor.org/stable/23593740
[4] Chughtai, Ismat. A Life in Words: Memoirs. UK: Penguin UK, 2013. Print.

[5] Das, Kamala. My Story. India: D C Books, 2011. Print.

[6] Deshpande, Shashi. Listen to Me. Noida, India: Westland Publications, 2018. Print.

[7] Forbes, Geraldine. The New Cambridge History of India, volume IV, part II, Women In Modern India. Cambridge: Cambridge University Press, 1996. Print.

[8] GUPTA, R. (1993). FEMINISM AND MODERN INDIAN LITERATURE. Indian Literature, $36(5$ (157)), 179-189. Retrieved from www.jstor.org/stable/23339720

[9] Josephine, Mary Elizabeth. Feminist concern in the select novels of Shashi Deshpande. 2010. Retrieved from http://hdl.handle.net/10603/102096

[10] Sarkar, Tanika. Hindu Wife, Hindu Nation: Community, Religion and Cultural Nationalism. New Delhi: Permanent Black, 2001. Pdf.

[11] Haque, Mohammad Mozammel. "Prophet and Philosopher Mohammed: A Precursor of Feminism." International Journal of Linguistics and Literature (IJLL) 7.6 (2018): 15-42.

[12] Naudé, Alaric. "Female Korean Nursing Studentsviews toward Feminism." International, Journal of General Medicine and Pharmacy (IJGMP)8.5 (2019) 1-10

[13] Singha, Tanmoy. "THE REEXPLORATION OF THE ESSENCE OF FEMINISM IN DH LAWRENCE'S SONS AND LOVERS." IMPACT: International Journal of Research in Humanities, Arts and Literature (IMPACT: IJRHAL) 6.8 (2018) 337-342

[14] YADAV, SANJU, and ANJU YADAV. "GEORGE ELIOT'S THE MILL ON THE FLOSS: AN APPROACH TO FEMINISM." International Journal of English and Literature (IJEL) 6.4 (2016) 45-54 
[15] KAMRA, MADHU, and SEEMA ARORA. "SITA IS SITA: EXPLORING POST FEMINISM FICTIVE SLOT OF DINA MEHTA." International Journal of English and Literature (IJEL) 7.2 (2017) $35-40$

[16] BARATHI, S., and MI BABU. "FEMINISM IN INDIA: AN EASTERN PERSPECTIVE." International Journal of English and Literature (IJEL) 9.2 (2019) $71-76$ 